\title{
Biological Evaluation of a Nutritional Supplement Prepared with QPM Maize Cultivar BR 473 and other Traditional Food Items
}

\author{
Heberth de Paula ${ }^{1 *}$, Rinaldo C. Santos ${ }^{2}$, Marcelo E. Silva ${ }^{2}$, Enara C. S. Glória ${ }^{2}$, Maria \\ Lúcia Pedrosa ${ }^{3}$, Nízia A. V. Almeida ${ }^{4}$, Alexandre S. V. Costa ${ }^{5}$ and Luiz Cosme C. \\ Malaquias ${ }^{5}$ \\ ${ }^{1}$ Departamento de Alimentos; Escola de Nutrição; ${ }^{2}$ Departamento de Ciências Biológicas; ${ }^{3}$ Universidade Federal \\ de Ouro Preto; 35400-000; Ouro Preto - MG - Brazil. ${ }^{4}$ Secretaria Municipal de Educação de Governador \\ Valadares; Secretaria Municipal de Saúde de Governador Valadares. ${ }^{5}$ Universidade do Vale do Rio Doce - \\ UNIVALE; Vale do Rio Doce - MG - Brazil
}

\begin{abstract}
Quality Protein Maize (QPM) cultivar BR 473 was employed, together with soybean flour, brown sugar, banana meal and oat meal, for the preparation of a nutritional supplement.. 21-day old male Fisher rats were fed diets containing the supplement as a protein source, both with and without soybean flour; casein diets with 10 or $7 \%$ protein served as respective controls. Protein Efficiency Ratio (PER), Net Protein Utilization (NPU), Net Protein Retention (NPR) and Digestibility were determined. Blood biochemical parameters (glucose, cholesterol, urea, hemoglobin, albumin and total protein) were also measured in the animals and showed that all were in good health condition at the end of the experiment. The obtained results for PER, NPU and NPR indicated that the supplement prepared with QPM maize cultivar BR 473 was a good protein source, especially when soybean flour was added.
\end{abstract}

Key words: QPM Maize, protein, biological evaluation, nutritional supplement

\section{INTRODUCTION}

The prevalence of malnutrition among low income populations in Brazil has led to the utilization of "alternative" food ingredients, such as powdered cassava and sugar beet leaves, wheat and rice bran and powdered egg shell, among others, as nutritional supplements (Santos, 2001). Nevertheless the results obtained are highly disputed, both in the practical and the experimental fields and antinutritional factors are believed to play important roles in the absortion and/or utilization of nutrients by the target organisms (Torin et al., 1995; Amaya-Farfán, 1998; Tramonte, 2000). In this context, the search for supplements using traditional and nutritive but low cost foods is under way.

Quality protein maize (QPM) is one of these foods (Paes and Bicudo, 1995). Cultivar BR 473, developed by Brazilian Enterprise of Agricultural Research (EMBRAPA), contains $9.04 \%$ protein, $4.44 \%$ fat, $0.40 \%$ fiber, $75.3 \%$ carbohydrate, $0.59 \%$ minerals and is rich in lysine $(0.40 \%)$ and tryptophan (0.09\%) (Paes, 1994). It is employed in the preparation of a nutritional supplement, together with soybean flour, brown sugar, banana

\footnotetext{
* Author for correspondence
} 
meal and oat meal, utilized in the project "Production and consumption of QPM BR 473 maize in the recovery of malnourished children in the municipality of Governador Valadares", carried out by local authorities, University of Vale do Rio Doce and Pastoral da Criança. The present work aimed at evaluating biologically this supplemnt in diets both with and without the addition of soybean flour and comparing their protein quality with that of casein diets with similar protein contents.

Table 1 - Composition of the QPM BR 473 supplements with (A) and without (B) soybean flour (values in \% w/w)

\begin{tabular}{|c|c|c|}
\hline Ingredients & 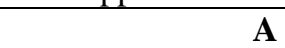 & 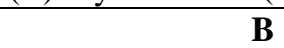 \\
\hline QPM BR 473 whole flour & 45 & 60 \\
\hline Soybean flour & 15 & 00 \\
\hline Brown sugar & 10 & 10 \\
\hline Banana meal & 20 & 20 \\
\hline Oat meal & 10 & 10 \\
\hline Total & 100 & 100 \\
\hline
\end{tabular}

Table 2 - Composition of the diets (\% w/w). (A) Control 10\%; (B) Control 7\%; (C) Protein-free; (D) Experimental with Soybean flour; (E) Experimental without Soybean flour.

\begin{tabular}{lrrrr|rr}
\hline \multicolumn{1}{c}{ Ingredients } & \multicolumn{1}{c}{$\boldsymbol{A}$} & $\boldsymbol{B}$ & $\boldsymbol{C}$ & $\boldsymbol{D}$ & $\boldsymbol{E}$ \\
\hline Casein $^{1}$ & 12.50 & 8.75 & - & - & - \\
Salt mixture $^{2}$ & 5.0 & 5.0 & 5.0 & 5.0 & 5.0 \\
Vitamin mixture $^{2}$ & 1.0 & 1.0 & 1.0 & 1.0 & 1.0 \\
Soybean oil & 8.0 & 8.0 & 8.0 & 6.0 & 6.0 \\
Choline & 0.04 & 0.04 & 0.04 & 0.04 & 0.04 \\
Cellulose & 1.0 & 1.0 & 1.0 & 1.0 & 1.0 \\
Corn starch & 72.46 & 76.21 & 84.96 & 11.21 & - \\
Supplement & - & - & - & 75.75 & 86.96 \\
\hline
\end{tabular}

${ }^{1}$ Casein contained $80,0 \% \mathrm{w} / \mathrm{w}$ protein

${ }^{2}$ According to AOAC, 1975

Table 3 - Chemical composition of the diets (\% w/w). (A) Control 10\%; (B) Control 7\%; (C) Protein-free; (D) Experimental with Soybean flour; (E) Experimental without Soybean flour

\begin{tabular}{lrrrrrr} 
& $\boldsymbol{A}$ & $\boldsymbol{B}$ & $\boldsymbol{C}$ & $\boldsymbol{D}$ & \multicolumn{1}{c}{$\boldsymbol{E}$} \\
\hline Protein & 10,22 & 7,23 & 0,25 & 9,65 & 6,62 \\
Ashes & 5,36 & 5,28 & 5,08 & 6,88 & 6,69 \\
Fat & 8,01 & 8,01 & 8,00 & 7,30 & 7,31 \\
Moisture & 10,64 & 10,58 & 10,20 & 6,83 & 6,66 \\
Carbohidrate & 64,76 & 67,89 & 75,46 & 68,14 & 71,47 \\
Fiber & 1,01 & 1,01 & 1,01 & 1,20 & 1,25 \\
\hline
\end{tabular}

\section{MATERIALS AND METHODS}

Nutritional supplements - The proposed supplements were prepared by mixing thoroughly its ingredients and their composition is shown in Table 1.

Animals and diets - 21-day old male Fisher rats were divided randomly into five groups of 20 animals each, housed in individual wire cages and fed the diets shown in Table 2; diets were approximately isocaloric and the protein contents of the control diets were in consonance with those of the experimental ones, that is 10 and $7 \% \mathrm{w} / \mathrm{w}$ were controls for respective experimental diet with soybean flour and experimental without it. The chemical composition of the diets is shown in Table 3.

Biological assay - Biological parameters were determined as described by Pellet and Young, 
(1980). Food consumption and weight gain by the animals were recorded weekly.

Net protein utilization (NPU) was calculated by the difference in carcass nitrogen (as expressed by nitrogen in left hind leg) between rats fed the test diets and those fed a protein-free diet. After 10 days of experiment, half of the rats were sacrificed and the left hind leg was excised and weighed. Nitrogen was determined. The following equation was used for NPU evaluation:

$N P U=[N$ in carcass (test group) $-N$ in carcass (protein-free group) $] / N$ ingested by test group

Net protein ratio (NPR) was calculated by the difference in body weight changes between the test group and the protein-free group, using the following equation:

$\mathrm{NPR}=\frac{\text { weight gain }(\text { test group })+\text { weight loss }(\text { protein }- \text { free group })}{\text { protein ingested by test group }}$

Protein efficiency ratio (PER) was calculated by the ratio of weight gain $(\mathrm{g}) /$ protein intake $(\mathrm{g})$, after 28 days for each of the remaining animals.

Digestibility (D); From the 14th to the 21st day of experiment, the feces were collected daily, dried at $105^{\circ} \mathrm{C}$, weighed and its nitrogen content determined. $\mathrm{D}$ was evaluated through the following equation:

$$
\mathrm{D}=\frac{\text { nitrogen intake }- \text { fecal nitrogen }}{\text { nitrogen intake }} \times 100
$$

Biochemical determinations - Blood cholesterol, glucose, albumin, urea, total protein and hemoglobin were determined with commercial kits (Labtest Diagnóstica S. A., Lagoa Santa, Minas Gerais, Brazil).

Statistical analysis - All results were submitted to analysis of variance using the software EPISTAT ( T. L. Gustafson, Round, Tx, EUA)

\section{RESULTS}

Data relative to food ingestion, weight gain and feces weight are depicted in Table 4. Animals fed the diets containing the supplements, both with and without soybean, ingested as much food as did the control $10 \%$ protein group and a bit more than the $7 \%$ protein controls. On the other hand, weight gain was statistically similar when experimental groups were compared with their respective controls. Nevertheless, when food efficiency (weight gain/food ingestion) was considered, animals receiving the supplements showed values comparable to their respective controls $(24.2 \%$, $21.9 \%, 14.8 \%$ and $11.7 \%$, respectively for control $10 \%$, experimental with soybean, control $7 \%$ and experimental without soybean) The amount of feces excreted by animals that ingested the diets containing the supplements was higher than their respective controls.

In Table 5 are shown the figures obtained when protein quality was biologically assessed. PER values were similar for all groups, except for the one fed the diet containing supplement without soybean flour. On the other hand, rats on all diets presented statistically equal values for NPU. In relation to NPR, animals receiving the diet made employing the supplements with or without soybean flour showed patterns statistically similar to their respective (10 and $7 \%$ protein) controls.

As regards the digestibility, casein diets were statistically similar to each other and same happened with the experimental diets.

Table 6 shows the biochemical characteristics found in the blood of the animals fed with various diets. As seen, values were statistically similar in all parameters, except for hemoglobin, which was slightly higher in the group that received diet containing supplement with soybean flour as compared to its control (10\% protein).

Table 4 - Food ingestion, weight gain and feces weight of animals fed control 10\% (A), control 7\% (B), Protein-free (C), Experimental with Soybean Flour (D) or Experimental without Soybean flour (E) diets ${ }^{\mathbf{1 , 2}}$

\begin{tabular}{lc|c|c|c|c} 
& $\mathbf{A}(\mathrm{g})$ & $\mathbf{B}(\mathrm{g})$ & $\mathbf{C}(\mathrm{g})$ & $\mathbf{D}(\mathrm{g})$ & $\mathbf{E}(\mathrm{g})$ \\
\hline Food ingestion & $326.5 \pm 21.8^{\mathrm{a}}$ & $276.0 \pm 41.5^{\mathrm{b}}$ & $217.4 \pm 7.8^{\mathrm{c}}$ & $356.0 \pm 41.4^{\mathrm{a}}$ & $324.7 \pm 9.2^{\mathrm{a}}$ \\
Weight gain & $79.0 \pm 9.3^{\mathrm{a}}$ & $41.0 \pm 13.1^{\mathrm{b}}$ & $17.4 \pm 4.6^{\mathrm{c}}$ & $78.7 \pm 9.7^{\mathrm{a}}$ & $38.4 \pm 5.8^{\mathrm{b}}$ \\
Feces weight & $14.5 \pm 1.6^{\mathrm{a}}$ & $12.0 \pm 1.9^{\mathrm{a}}$ & $3.7 \pm 0.4^{\mathrm{d}}$ & $53.8 \pm 6.3^{\mathrm{b}}$ & $43.8 \pm 3.9^{\mathrm{c}}$ \\
\hline
\end{tabular}

${ }^{1}$ Mean \pm standard deviation indicated

${ }^{2}$ Different superscript letters in the same line indicate significant difference $(\mathrm{p}<0.05)$ 
Table 5 - Protein efficiency ratio (PER), net protein utilization (NPU), net protein ratio (NPR) and digestibility (D) of animals fed control 10\% (A), control 7\% (B), Experimental with Soybean Flour (D) or Experimental without Soybean flour (E) diets ${ }^{1,2}$

\begin{tabular}{lc|c|c|c} 
& A & B & D & E \\
\hline PER & $2.41 \pm 0.17^{\mathrm{a}}$ & $2.10 \pm 0.58^{\mathrm{a}}$ & $2.21 \pm 0.11^{\mathrm{a}}$ & $1.69 \pm 0.25^{\mathrm{b}}$ \\
NPU & $102.28 \pm 2.97^{\mathrm{a}}$ & $114.18 \pm 29.63^{\mathrm{a}}$ & $94.86 \pm 5.52^{\mathrm{a}}$ & $95.12 \pm 4.64^{\mathrm{a}}$ \\
NPR & $3.96 \pm 0.48^{\mathrm{a}}$ & $2.69 \pm 1.36^{\mathrm{b}, \mathrm{c}}$ & $3.77 \pm 0.42^{\mathrm{a}, \mathrm{c}}$ & $1.89 \pm 0.53^{\mathrm{b}}$ \\
Digestibility & $91.8 \pm 0.7^{\mathrm{a}}$ & $91.3 \pm 1.5^{\mathrm{a}}$ & $72.3 \pm 2.8^{\mathrm{b}}$ & $69.3 \pm 14.1^{\mathrm{b}}$ \\
\hline
\end{tabular}

${ }^{1}$ Mean \pm standard deviation indicated

${ }^{2}$ Different superscript letters in the same line indicate significant difference $(\mathrm{p}<0.05)$

Table 6 - Blood biochemical parameters of animals fed control 10\% (A), control 7\% (B), Protein-free (C), Experimental with Soybean Flour (D) or Experimental without Soybean flour (E) diets ${ }^{\mathbf{1 2}}$

\begin{tabular}{lc|c|c|c|c|c} 
& $\mathbf{A}$ & $\mathbf{B}$ & $\mathbf{C}$ & $\mathbf{D}$ & $\mathbf{E}$ & $\mathbf{R . ~ V}^{3}$ \\
\hline Cholesterol(mg/dL) & $59.35 \pm 24.75^{\mathrm{a}}$ & $63.40 \pm 12.44^{\mathrm{a}}$ & $44.22 \pm 24.62^{\mathrm{a}}$ & $67.64 \pm 8.42^{\mathrm{a}}$ & $67.71 \pm 8.59^{\mathrm{a}}$ & $27(10-54)$ \\
Glucose (mg/dL) & $139.33 \pm 59.06^{\mathrm{a}}$ & $133.20 \pm 13.89^{\mathrm{a}}$ & $139.01 \pm 16.48^{\mathrm{a}}$ & $152.54 \pm 12.14^{\mathrm{a}}$ & $141.34 \pm 11.92^{\mathrm{a}}$ & $75(50-135)$ \\
Albumin (g/dL) & $3.22 \pm 1.31^{\mathrm{a}}$ & $3.31 \pm 0.39^{\mathrm{a}}$ & $2.89 \pm 0.18^{\mathrm{a}}$ & $3.13 \pm 0.27^{\mathrm{a}}$ & $2.81 \pm 0.24^{\mathrm{a}}$ & $3.7(2.7-5.1)$ \\
Urea (mg/dL) & $34.91 \pm 15.57^{\mathrm{a}}$ & $29.66 \pm 2.14^{\mathrm{a}}$ & $29.40 \pm 3.89^{\mathrm{a}}$ & $28.70 \pm 2.62^{\mathrm{a}}$ & $27.48 \pm 3.66^{\mathrm{a}}$ & $31(10.7-62.1)$ \\
Total protein $(\mathrm{g} / \mathrm{dL})$ & $5.25 \pm 2.19^{\mathrm{a}}$ & $5.13 \pm 0.32^{\mathrm{a}}$ & $4.90 \pm 0.54^{\mathrm{a}}$ & $5.38 \pm 0.46^{\mathrm{a}}$ & $5.00 \pm 0.22^{\mathrm{a}}$ & $7.6(4.7-8.2)$ \\
Hemoglobin $(\mathrm{g} / \mathrm{dL})$ & $12.83 \pm 1.26^{\mathrm{a}}$ & $14.27 \pm 1.03 \mathrm{a} \mathrm{a}^{\mathrm{b}}$ & $13.54 \pm 0.58^{\mathrm{a}, \mathrm{b}}$ & $14.31 \pm 0.79^{\mathrm{b}}$ & $13.65 \pm 0.91^{\mathrm{a}, \mathrm{b}}$ & $14.2(11-17)$ \\
\hline
\end{tabular}

${ }^{1}$ Mean \pm standard deviation indicated

${ }^{2}$ Different superscript letters in the same line indicate significant difference $(\mathrm{p}<0.05)$

${ }^{3}$ Reference values, CCAC, 1984: average value (range)

\section{DISCUSSION}

The use of food supplements made with alternative ingredients, such as used in this study, in the recovery of malnourished children is controversial. Câmara and Madruga (2001) did not find significant levels of toxic or antinutritional factors in a supplement made with alternative ingredients, the so called "multimistura". On the other hand, biological assays with rats didn't show any advantages in its utilization (Boaventura et al., 2000; Melo et al., 2000; Tramonte et al., 2000). If one agrees that using low cost and nutritive supplements is an important tool in the recovery or maintenance of good nutritional status in low income populations QPM maize, with or without soybean flour, could be worth evaluation.

The weekly recording of food consumption and weight gain showed that the biological assay proceeded without abnormalities. As can be learnt from Table 4, food efficiency of the diets containing the proposed supplements was similar to their respective controls. As expected, feces weight was dependent on the amount of fiber in the diets (Table 3) and on food ingestion (Table 4), with the animals consuming the diet with soybean flour showing the highest value.
When nutritional indexes were investigated (Table 5), it was seen that QPM maize contributed for the improvement of protein quality of the supplement. NPU values were statistically similar in all cases. PER values did not differ statistically, except for animals ingesting the diet containing the supplement without soybean. It must be stressed that the effect of soybean flour addition was relevant, since this item represented only about $11 \% \mathrm{w} / \mathrm{w}$ of the diet but raised the PER value in about $30 \%$. This effect was confirmed by NPR that, taking into account the weight loss by the non-protein group, made similar the values of the experimental animals with their respective controls. As expected, the digestibilities of the 10 and $7 \%$ control diets were similar to each other but higher then that of the experimental ones, probably due to the fiber content of maize, banana and oat employed in the preparation of the supplements (Eggum 1995).

Assessment of blood biochemical parameters of the animals on the various diets (Table 6) showed their general health status; all of them presented statistically similar values for cholesterol, glucose and urea. When parameters more linked to protein metabolism (albumin, total protein and hemoglobin) were considered, it was seen that statistical differences were detected only in relation to 
hemoglobin, although all values fell within the range acceptable for the rat (CCAC, 1984).

In conclusion, the results obtained in the present work indicated that QPM maize BR 473 showed a good potential for utilization in nutritional supplements, especially when associated with soybean flour.

\section{RESUMO}

Milho de Qualidade Protéica (QPM) da cultivar BR 473, desenvolvida pela EMBRAPA está sendo empregado, juntamente com farinha de soja, açúcar mascavo, farinha de banana e farinha de aveia, na preparação de um suplemento nutricional, usado na recuperação de crianças desnutridas no município de Governador Valadares, MG. Reporta-se aqui o resultado da avaliação biológica deste suplemento. Ratos Fisher machos de 21 dias de idade foram alimentados com dietas contendo o suplemento como fonte de proteína, com ou sem farinha de soja; dietas de caseína com 10 ou $7 \%$ de proteína serviram como respectivos controles. Foram determinadas a Razão de Eficiência Protéica (REP), a Utilização Líquida de Proteína (ULP), a Razão Líquida de Proteína (RLP) e a Digestibilidade. Parâmetros bioquímicos sanguíneos (glicose, colesterol, uréia, hemoglobina, albumina, e proteína total) foram também medidos nos animais e mostraram que todos estavam em boas condições de saúde ao final do experimento. Os resultados obtidos para REP, ULP, RLP e Digestibilidade indicam que o suplemento preparado com o milho QPM cultivar 473 é uma boa fonte de proteína, especialmente quando a farinha de soja é adicionada.

\section{REFERENCES}

Amaya-Farfán, J. (1998), Alimentação alternativa: análise crítica de uma proposta de intervenção nutricional. Cad. Saúde Públ., 14 : (1), 201-212.

AOAC (1975), Official Methods of Analysis,. Association of Official Analytical Chemists, Washington, D.C.

Boaventura, G. T. et al. (2000), Avaliação biológica da multimistura. Paper presented at Simpósio SulBrasileiro de Alimentação e Nutrição. História, Ciência e Arte. Florianópolis, 26-28 April. pp. 29-34.
Câmara, F. S. and Madruga, M. S. (2001), Cyanic acid, phytic acid, total tannin and aflatoxin contents of a brazilian (Natal) multimistura preparation. Rev. Nutr., 14 : (1), 33-36.

Canadian Council on Animal Care - CCCA (1984), Guide to the care and use of experimental animals Otawa. pp. 85-88.

Eggum, B. O. (1995), The influence of dietary fibre on protein digestion and utilization in monogastrics. Arch. Tierernahr., 48, 89-95.

Melo, S. S. et al. (2000), Efeito da multimistura no crescimento e desenvolvimento de ratos desnutridos $e$ eutróficos. Paper presented at Simpósio Sul-Brasileiro de Alimentação e Nutrição. História, Ciência e Arte. Florianópolis, 26-28 April. pp. 251-255.

Paes, M. C. D. (1994), Perspectivas nutricionais do milho de alta qualidade protéica. Sete Lagoas : EMBRAPA - Centro Nacional de Pesquisa de Milho e Sorgo.

Paes, M. C. D. and Bicudo, M. H. (1995), Nutritional Perspectives of Quality Protein Maize. In: Larkins, B. A. and Mertz, E. T. (eds.). Quality Protein Maize: 1964-1994. Proceedings of the International Symposium on Quality Protein Maize. Sete Lagoas. pp. 65-78.

Pellet, P. L. and Young, V. R. (1980), Evaluation of protein quality in experimental animals. In: Nutritional Evaluation of Protein Foods. Tokio : The United Nations University. pp. 41-57.

Santos, L. A. S. et al. (2001), Uso e percepções da alimentação alternativa no estado da Bahia: um estudo preliminar. Rev. Nutr., 14 : (supl.), 35-40.

Torin, H. R et al. (1995), Alimentação alternativa: posição da Sociedade Brasileira de Pediatria. Jornal de Pediatria, 71 : (4), 235-236.

Tramonte, V. L. C. G. et al. (2000), Efeito de uma multimistura como fonte de vitaminas para ratas lactantes e seus reflexos sobre o peso da prole. Paper presented at Simpósio Sul-Brasileiro de Alimentação e Nutrição. História, Ciência e Arte. Florianópolis, 26-28 April. pp. 257-261.

Tramonte, V. L. C. G. (2000), Multimistura $x$ estratégias alimentares: uma avaliação científica. Paper presented at Simpósio Sul-Brasileiro de Alimentação e Nutrição. História, Ciência e Arte. Florianópolis, 26-28 April. pp. 35-39.

Received: July 04,2002 ; Revised: October 09, 2002; Accepted: September 19, 2003. 